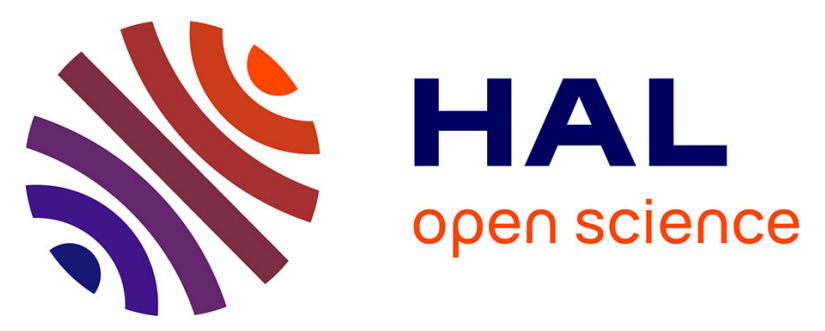

\title{
New data on the paleobiology of the Gravettian individual L2A from Cussac cave (Dordogne, France) through a virtual approach
}

Pierre Guyomarc'H, Mathilde Samsel, Patrice Courtaud, Pascal Mora, Bruno Dutailly, Sébastien Villotte

\section{To cite this version:}

Pierre Guyomarc'H, Mathilde Samsel, Patrice Courtaud, Pascal Mora, Bruno Dutailly, et al.. New data on the paleobiology of the Gravettian individual L2A from Cussac cave (Dordogne, France) through a virtual approach. Journal of Archaeological Science: Reports, 2017, 14, pp.365-373. 10.1016/j.jasrep.2017.06.005 . hal-02266512

\section{HAL Id: hal-02266512 \\ https://hal.science/hal-02266512}

Submitted on 19 Feb 2021

HAL is a multi-disciplinary open access archive for the deposit and dissemination of scientific research documents, whether they are published or not. The documents may come from teaching and research institutions in France or abroad, or from public or private research centers.
L'archive ouverte pluridisciplinaire HAL, est destinée au dépôt et à la diffusion de documents scientifiques de niveau recherche, publiés ou non, émanant des établissements d'enseignement et de recherche français ou étrangers, des laboratoires publics ou privés. 
TITLE: New data on the paleobiology of the Gravettian individual L2A from Cussac cave (Dordogne, France) through a virtual approach

AUTHORS: GUYOMARC'H Pierre (a), SAMSEL Mathilde (a), COURTAUD Patrice (a), MORA Pascal (b), DUTAILLY Bruno (a,b), VILLOTTE Sébastien (a)

AFFILIATIONS: (a) UMR 5199 PACEA, Université de Bordeaux, CNRS, MCC; (b) UMS 3657 Archéovision, Université Bordeaux Montaigne, CNRS

FUNDING SOURCE: This work was supported by the Agence Nationale de la Recherche (ANR) GRAVETT'OS (grant number ANR-15-CE-0004)

CORRESPONDING AUTHORS: Sébastien Villotte, Pierre Guyomarc'h

ADDRESS: Université de Bordeaux, UMR 5199 PACEA, Bat B8, Allée Geoffroy St Hilaire, CS 50023, 33615 Pessac Cedex

EMAIL: sebastien.villotte@u-bordeaux.fr; pierre.guyomarch@u-bordeaux.fr

ABSTRACT: One of several elements making Cussac cave an exceptional site is the preservation of many prehistoric human remains lying on the ground, including an individual in a bear nest (Locus 2) in ventral decubitus, subject L2A. The protected status of the site does not allow for excavations or direct manipulation of the remains, at least for the near future. Thus, the tools of virtual anthropology were employed to further study this individual, after preliminary analyses in situ in 2014 raised several questions on its biological characteristics. A high-resolution 3D photogrammetric record of Locus 2 allowed for the virtual reconstruction of the ossa coxarum and cranium to be measured in TIVMI. Metric data from the ossa coxarum were used to apply the DSP, which indicated a male sex assessment for the left side. The linear variables and log shape ratios extracted from the cranium were compared to a reference sample composed of 46 Upper Paleolithic (UP) subjects. The cranial morphology of L2A is closer to the male variability for the UP, but displays an unusual pattern, with a short cranial height and a wide splanchnocranium. The biological peculiarities of this subject are discussed with regard to Gravettian funerary practices and the depositional context of Cussac cave.

KEYWORDS: Virtual Anthropology; Photogrammetry; Sexual dimorphism; Probabilistic sex diagnosis; Coxal bone; Skull; Upper Paleolithic 


\section{Introduction}

Since 2010, Cussac cave (Dordogne, France) underwent several extensive research campaigns that focused on several non-invasive archaeological and anthropological investigations (Ferrier, et al., 2016, Henry-Gambier, et al., 2013, Ledoux, et al., 2016, Villotte, et al., 2015). The cave hosts a unique combination of parietal art and human remains dating to the Gravettian $(31,000-22,000$ BP). The striking artistic elements consist of more than 150 engravings, mostly animal and human depictions, which represents one the richest corpora of European parietal art for the Gravettian (Aujoulat, et al., 2001, Jaubert, et al., 2016). Similarly, human skeletal remains from this site significantly enriched the fossil record of the Upper Paleolithic of Europe, a period for which well-preserved human skeletons are relatively rare (Henry-Gambier, 2005). Several hundred human remains (fragments or complete bones) are scattered on the surface of the cave in at least three different loci.

One of the loci, Locus 2, consists of a well-represented skeleton - partially covered by clay contained in a bear nest. Given the absence of duplicate elements, all the bones are attributed to the same individual, subject L2A. The current arrangement of the bones in the locus follows a logical anatomical pattern (Figure 1), indicating that the individual was deposited in ventral decubitus (Henry-Gambier, et al., 2013, Villotte, et al., 2015). The other loci contain commingled human remains from several individuals. The consistency between the artistic style of the parietal engravings and two ${ }^{14} \mathrm{C}$ dates suggests that the human activity in the cave spans between 29,000 and 28,000 cal BP (Jaubert, et al., 2016).

Due to its unique characteristics, the Cussac cave is now protected under the national heritage status. The site is closed to the public, and even the scientific team (Programme Commun de Recherche, PCR Cussac) has a relatively short window of time for intervention each year due to the high concentration of $\mathrm{CO}_{2}$ in the cave between spring and fall. Moreover, to ensure the protection of the preserved floor, no excavations nor samplings are planned in the near future. Given these limitations, the bioanthropological studies focus on non-invasive analyses, consisting, to date, of in situ observations and measurements of the visible elements. Using these methods, a preliminary study of L2A had been performed from a metallic walkway specially extended above the Locus 2 (Villotte, et al., 2015). Before and after this study, the locus was virtually documented via 3D photogrammetry, allowing for additional research on these human remains.

Based on the characteristics of the auricular surface (Schmitt, 2005), the first evaluation of L2A estimated an age-at-death between 20 to 49 years (Villotte, et al., 2015). The sex determination was done through visual scoring of the visible morphology of the os coxae (Brůžek, 2002), and from measurements computed in a probabilistic tool for sexual diagnosis, DSP (Murail, et al., 2005). These morphometric methods applied to the left os coxae gave a male diagnosis. However, the presence of shared sexual traits in the morphoscopic evaluation, as well as a very low stature for this individual (outside the Gravettian range) called for further investigation into the sex of L2A (Villotte, et al., 2015).

Moreover, the body proportions of this individual raised the question of a possible developmental anomaly (Villotte, et al., 2015), an occurrence which appears to be abnormally frequent in the late Pleistocene sample (Wu, et al., 2013). In addition, L2A was laid in a unique context for an Upper Paleolithic burial (a bear nest), and in ventral decubitus, a very 
uncommon position for the Gravettian period (Henry-Gambier, 2008). A new analysis of this individual will therefore contribute to the debate on possible specific burial treatments of pathological individuals during the Upper Paleolithic (Formicola, 2007, Formicola, et al., 1990, Formicola, et al., 2001, Mallegni and Fabbri, 1995, Pettitt, 2013, Sparacello, et al., n.d., Villotte, et al., 2017).

To this end, we employed a high-resolution photogrammetric tridimensional (3D) reconstruction to obtain virtual models of L2A's bones, and applied the now commonly used methods of virtual anthropology (Weber and Bookstein, 2011). We present in this report a new analysis of the L2A pelvis with the DSP method, as well as an analysis of its cranial morphology in comparison with a sample from the Upper Paleolithic.

\section{Material and Methods}

\subsection{The 3D photogrammetric model}

Several photogrammetric acquisitions of the Cussac cave areas that include human remains were performed between 2012 and 2015, with global views and close-ups of the visible osseous elements. This allows for a 3D modelling and isolation of the different bones; the resulting 3D model of Locus 2 is displayed in Figure 1. More than 700 photographs were processed with a Nikon d700 (zoom 24-70 2.8 used at $24 \mathrm{~mm}$ ) during three different campaigns using Photoscan (AgisoftC) and PMVS (Furukawa and Ponce, 2010) software. This resulted in several 3D point clouds with a spatial resolution ranging from 1 to $0.5 \mathrm{~mm}$. Points clouds were meshed and scaled using local physical scales and topographic points (with $\mathrm{x}, \mathrm{y}, \mathrm{z}$ coordinates, acquired by a Leica $\bigcirc$ total station).



Figure 1. Visualization of the global 3D photogrammetric record of the Locus 2 with textures (in MeshLab@, ISTI, v.1.3.4) 


\subsection{Methodology for the ossa coxarum analysis}

The 3D photogrammetric models of the ossa coxarum of L2A were extracted from the global model to allow more accurate measurements (Figure 2). In order to reveal key anatomical areas for age and sex estimation, a layer of clay was removed from the left os coxae during one of the campaigns (Villotte, et al., 2015). Figure 2 displays the 3D models of the bones after cleaning (i.e. posterior to the record in Figure 1). The ossa coxarum were isolated with the Geomagic ${ }^{\circledR}$ Wrap 2014 software.
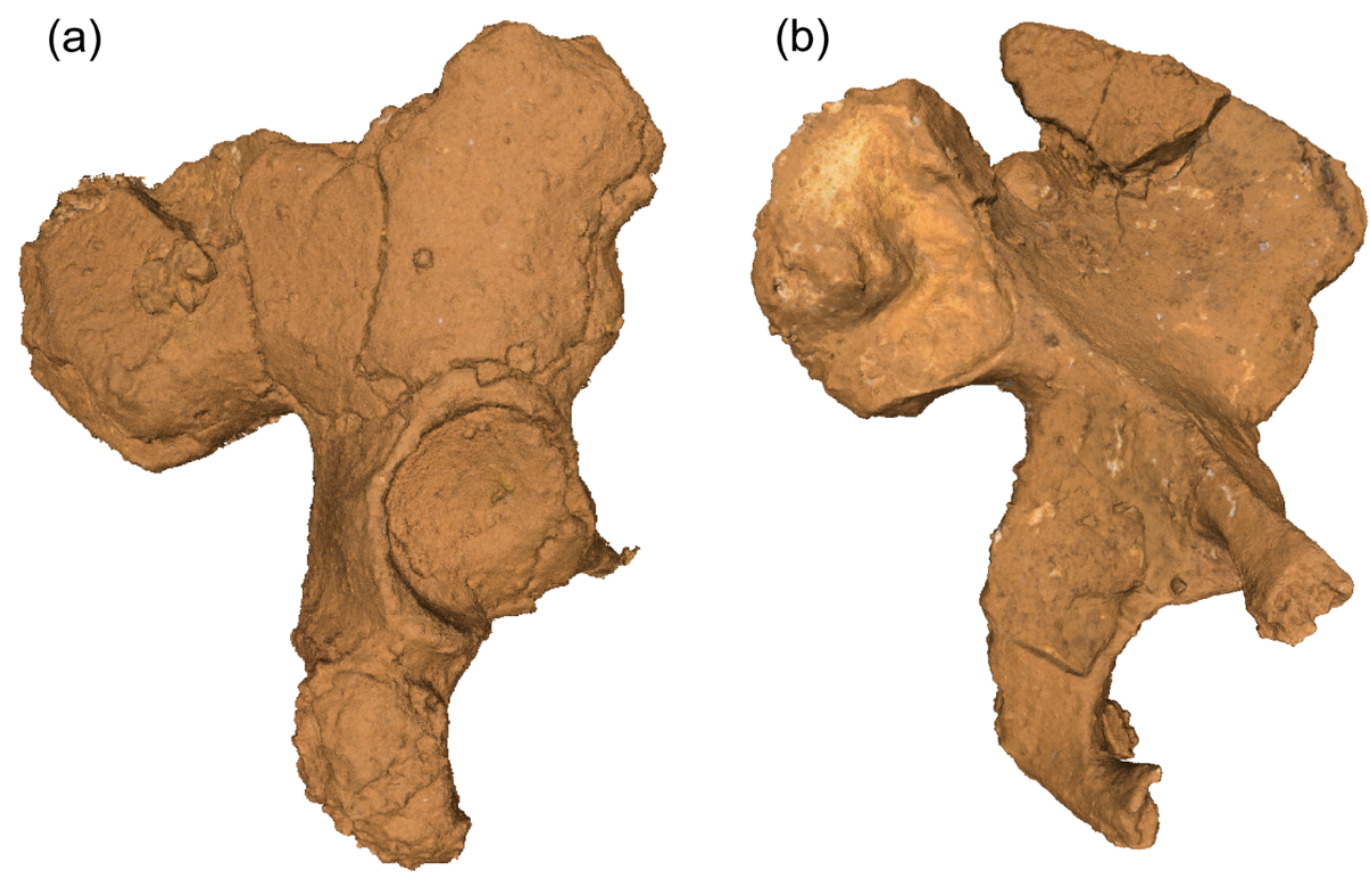

Figure 2. Visualization of the isolated 3D models of the ossa coxarum of L2A with textures (in MeshLab®, ISTI, v.1.3.4): (a) right os coxae in lateral view; (b) left os coxae in medial view.

One of the most objective and reliable morphometric methods to assess the sex from the pelvic region is DSP (Murail, et al., 2005). DSP has been used in the preliminary in situ study of Cussac L2A, and resulted in a male assessment from direct measurements of the left os coxae (Villotte, et al., 2015). As this method was already validated for use in a virtual approach (Chapman, et al., 2014), measurements were recorded for this study on the virtual model of the ossa coxarum in TIVMI software (Dutailly, 2016) to confirm the results previously obtained with traditional measures (Villotte et al., 2015).

\subsection{Methodology of analysis for the cranial morphology}

The refined photogrammetric acquisition of the cranium (Figure 3) was also cropped in Geomagic ${ }^{\circledR}$ Wrap 2014 for virtual processing. A layer of clay deposit covers most of the human remains in Locus 2, with a variable thickness; the teeth and spheno-occipital suture were cleaned during the in situ analysis for age estimation purposes (Villotte et al., 2015). The 
mandible, although present, was not included in the present study, as it would require an extensive reconstruction of the non-visible parts (this element lies on its inferior surface and is partly covered by clay).


Figure 3. Visualization of the 3D model of L2A cranium with textures (in MeshLabC, ISTI, v.1.3.4): (a) isolated cranium in frontal view; (b) cranium in left lateral view; (c) cranium in inferior view.

The cranium of L2A is lying on its right side, thus several anatomical parts are non-visible on the model (Figure 3a). Consequently, the available landmarks on the left side were mirrored in TIVMI, using the sagittal plane as a reference (passing through the landmarks nasion, prosthion and bregma), to obtain the corresponding right points and ensure the collection of sufficient craniometrics data (see Table 2). The linear measurements were extracted in TIVMI through the Segment $3 D$ plugin, or using projections on planes when necessary (Guyomarc'h, et al., 2014). The landmarks that were covered by a layer of clay were manually corrected to account for this layer, or were not collected when the thickness of the sediment could not be evaluated. At this stage of the analysis, this correction can only be an estimation based on comparisons with the areas not showing clay deposits (i.e. 1 to $2 \mathrm{~mm}$ thickness on the left lateral vault).

From the list of variables defined by Martin (Bräuer, 1988), a subsample of measurements were selected following their availability on L2A and their representation in the comparative sample. Table 1 lists the codes, measurements, and corresponding landmarks of the 30 retained variables, along with 18 cranial indices.

\begin{tabular}{|l|l|l||l||l|l|l|l|}
\hline $\begin{array}{l}\text { Code } \\
\text { (Bräuer, } \\
\text { 1988) }\end{array}$ & Variable & Landmarks/measurements & L2A & $\begin{array}{l}\text { Code } \\
\text { (Bräuer, } \\
\text { 1988) }\end{array}$ & Variable & Landmarks/measurements & L2A \\
\hline M1 & $\begin{array}{l}\text { Maximum cranial } \\
\text { length }\end{array}$ & Glabella - Opisthocranion & 191.1 & M54 & Nasal breadth & Apertion L - Apertion R & 27.7 \\
\hline M2 & $\begin{array}{l}\text { Glabella-inion } \\
\text { length }\end{array}$ & Glabella - Inion & 179.7 & M55 & Nasal height & Nasospinale - Nasion & 42.3 \\
\hline M3 & $\begin{array}{l}\text { Glabella-lambda } \\
\text { length }\end{array}$ & Glabella - Lambda & 179.9 & M60 & $\begin{array}{l}\text { Maxillo- } \\
\text { alveolar length }\end{array}$ & Prosthion - Alveolare & 52.7 \\
\hline M5 & $\begin{array}{l}\text { Length of the skull } \\
\text { base }\end{array}$ & Basion - Nasion & 98.6 & M61 & $\begin{array}{l}\text { Maxillo- } \\
\text { alveolar } \\
\text { breadth }\end{array}$ & $\begin{array}{l}\text { Ectomolare L - Ectomolare } \\
R^{*}\end{array}$ & 70.2 \\
\hline
\end{tabular}




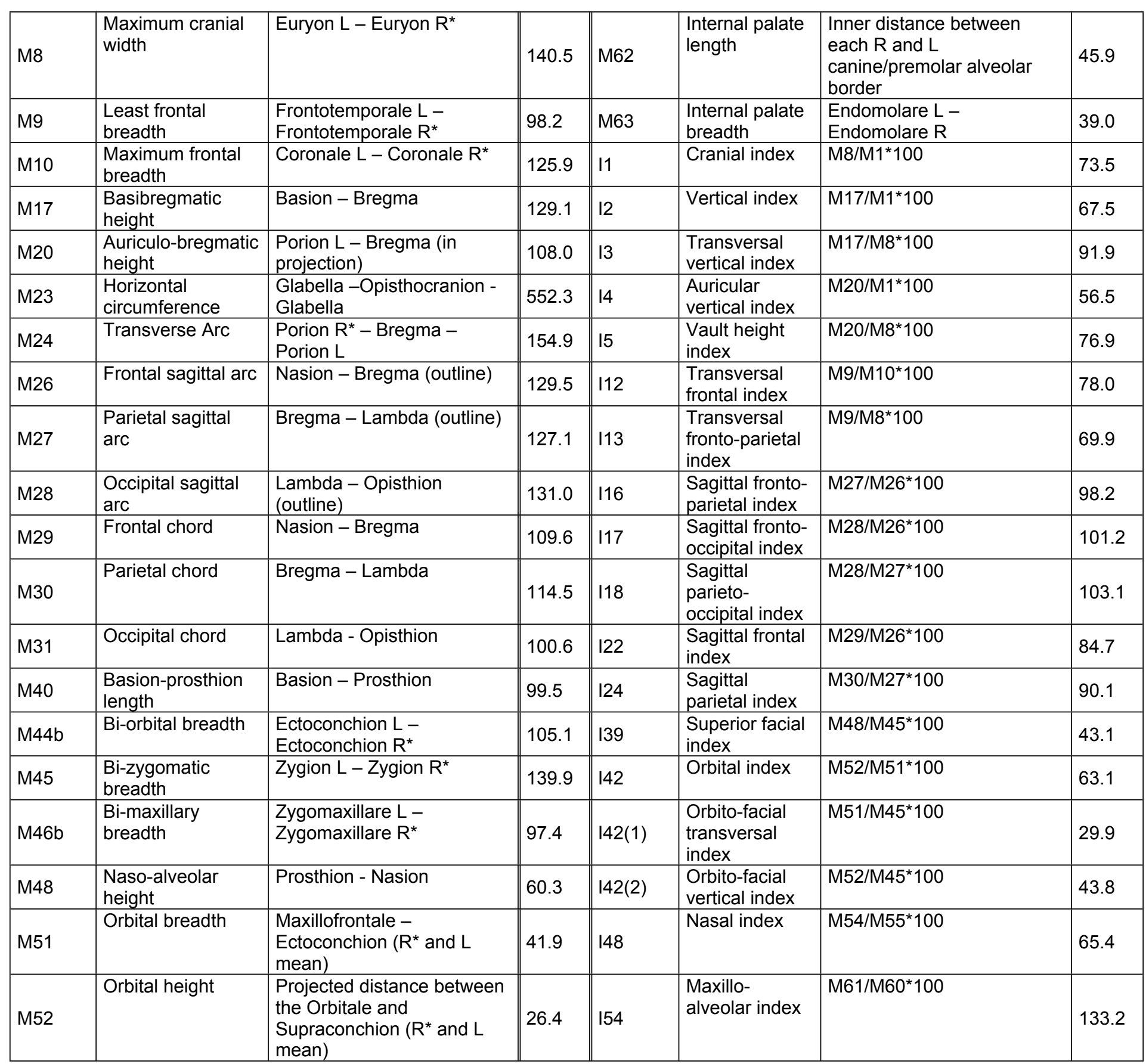

Table 1. Variables used in the study and raw data for L2A (in $\mathrm{mm}$ ). * indicates the missing landmarks estimated for L2A.

\subsection{Cranial comparative sample}

Data on the comparative sample were mainly collected from the literature from specimens with relatively well-preserved crania, with a known context of discovery, and available direct dating if possible. All the selected individuals date to a period covering the Middle-Upper Paleolithic (MUP) and the Late Upper Paleolithic (LUP). Some of these remains have recently been tested genetically (see Fu, et al. (2016) for V1, O1, DV13, DV14, B1; Tarsi, et al. (2006) for AC5), and the sex of most subjects was identified from their ossa coxarum 
morphology (CM1, AP1, BT2, BC1, BG1, BG5, GE5, PG25, DV3, DV16, PV1, S1, R6, AC2, AC4, AC3, AC12, IA, L1, LB4, LP5, SG1, ST1, OK1, OK2, S1). Additional specimen are used in the general comparison analyses, but are not included in the sex-related test (CM2, CM3, DV15, P3, P4, P9, P10, S5, B2, B3, R4, R6, AC12, C, RR1, CB). Table 2 lists the 46 subjects of the comparative sample with their source publications and the acronyms used in this study.

\begin{tabular}{|c|c|c|c|c|c|}
\hline Site & Specimen (Sex) & Localization & Period & Data source & Sex diagnosis \\
\hline Cro-Magnon & $\begin{array}{l}\text { CM1 (M), CM2*, } \\
\text { CM3* }^{*}\end{array}$ & France (SW) & MUP & $\begin{array}{l}\text { (Vallois and Billy, } \\
\text { 1965) }\end{array}$ & $\begin{array}{l}\text { (Gambier, et al., } \\
\text { 2006) }\end{array}$ \\
\hline Abri Pataud & AP1 (F) & France (SW) & MUP & (Billy, 1975) & (Villotte, 2009) \\
\hline $\begin{array}{l}\text { Dolní } \\
\text { Věstonice and } \\
\text { Pavlov }\end{array}$ & $\begin{array}{l}\text { DV3 (F), DV13 (M), } \\
\text { DV14 (M), DV15*, } \\
\text { DV16 (M), PV1 (M) }\end{array}$ & $\begin{array}{l}\text { Czech } \\
\text { Republic }\end{array}$ & MUP & (Sládek, et al., 2000) & $\begin{array}{l}\text { (Fu, et al., 2016, } \\
\text { Trinkaus and } \\
\text { Svoboda, 2006) }\end{array}$ \\
\hline Předmostí & $\mathrm{P}^{*}, \mathrm{P}^{*}, \mathrm{P}^{*}, \mathrm{P} 10^{*}$ & $\begin{array}{l}\text { Czech } \\
\text { Republic }\end{array}$ & MUP & $\begin{array}{l}\text { (Velemínská and } \\
\text { Brǔžek, 2008) }\end{array}$ & - \\
\hline Sunghir & S1 (M), S5* & Russia & MUP & (Trinkaus, et al., 2014) & (Villotte, 2009) \\
\hline Ostuni & $01(F)$ & Italy (S) & MUP & (Coppola, 2013) & (Villotte, 2009) \\
\hline Paglicci & PG25 (F) & Italy (S) & MUP & (Coppola, 2013) & (Villotte, 2009) \\
\hline Brno & B2 (I), B3 (I) & $\begin{array}{l}\text { Czech } \\
\text { Republic }\end{array}$ & MUP & (Coppola, 2013) & - \\
\hline $\begin{array}{l}\text { Grotte des } \\
\text { Enfants }\end{array}$ & GE5 (F) & Italy (N) & MUP & (Coppola, 2013) & $\begin{array}{l}\text { (Villotte, et al., } \\
\text { 2011) }\end{array}$ \\
\hline $\begin{array}{l}\text { Barma del } \\
\text { Caviglione }\end{array}$ & $\mathrm{BC} 1(\mathrm{~F})$ & Italy $(\mathrm{N})$ & MUP & $\begin{array}{l}\text { (De Lumley, 2016, } \\
\text { Guipert, et al., 2014) }\end{array}$ & $\begin{array}{l}\text { (De Lumley, } \\
\text { 2016) }\end{array}$ \\
\hline $\begin{array}{l}\text { Barma } \\
\text { Grande }\end{array}$ & $B G 1(M), B G 5(M)$ & Italy $(\mathrm{N})$ & MUP & $\begin{array}{l}\text { (De Lumley, 2016, } \\
\text { Graziosi, 1942) }\end{array}$ & $\begin{array}{l}\text { (De Lumley, } \\
\text { 2016, Villotte, et } \\
\text { al., 2011) }\end{array}$ \\
\hline $\begin{array}{l}\text { Baousso da } \\
\text { Torre }\end{array}$ & BT2 (M) & Italy $(\mathrm{N})$ & MUP & (Villotte, et al., 2017) & $\begin{array}{l}\text { (Villotte, et al., } \\
\text { 2011) }\end{array}$ \\
\hline Romito & $\mathrm{R} 6(\mathrm{~F}), \mathrm{R} 4^{*}, \mathrm{R} 6^{*}$ & Italy (S) & LUP & $\begin{array}{l}\text { (Mallegni and Fabbri, } \\
\text { 1995) }\end{array}$ & (Villotte, 2009) \\
\hline $\begin{array}{l}\text { Arene } \\
\text { Candide }\end{array}$ & $\begin{array}{l}\text { AC2 (M), AC3 (M), } \\
\text { AC4 (M), AC5 (M), } \\
\text { AC12 (M) }\end{array}$ & Italy $(\mathrm{N})$ & LUP & $\begin{array}{l}\text { (Paoli, et al., 1980, } \\
\text { Sergi, et al., 1974) }\end{array}$ & $\begin{array}{l}\text { (Tarsi, et al., } \\
\text { 2006, Villotte, } \\
\text { 2009) }\end{array}$ \\
\hline Le Bichon & B1 (M) & Switzerland & LUP & (Chauvière, 2008) & (Villotte, 2009) \\
\hline $\begin{array}{l}\text { Les } \\
\text { Iboussières }\end{array}$ & IA (M) & France $(\mathrm{S})$ & LUP & Personal observation & $\begin{array}{l}\text { Personal } \\
\text { observation }\end{array}$ \\
\hline Chancelade & $\mathrm{C}^{*}$ & France (SW) & LUP & Personal observation & - \\
\hline Rochereil 1 & RR1* & France (SW) & LUP & Personal observation & - \\
\hline Cap Blanc & $\mathrm{CB}^{*}$ & France (SW) & LUP & (von Bonin, 1935) & - \\
\hline Lafaye & L1 (F) & France (SW) & LUP & Personal observation & (Villotte, 2009) \\
\hline $\begin{array}{l}\text { Laugerie- } \\
\text { Basse }\end{array}$ & LB4 (M) & France (SW) & LUP & Personal observation & (Villotte, 2009) \\
\hline Le Peyrat & LP5 (M) & France $(\mathrm{S})$ & LUP & (Samsel, et al., 2016) & $\begin{array}{l}\text { (Samsel, et al., } \\
\text { 2016) }\end{array}$ \\
\hline $\begin{array}{l}\text { Saint Germain } \\
\text { la Rivière }\end{array}$ & SG1 (F) & France (SW) & LUP & Personal observation & $\begin{array}{l}\text { (Henry-Gambier, } \\
\text { et al., 2002) }\end{array}$ \\
\hline San Teodoro & ST1 (F) & Sicily & LUP & Personal observation & $\begin{array}{l}\text { Personal } \\
\text { observation }\end{array}$ \\
\hline Villabruna & V1 (M) & Italy $(\mathrm{N})$ & LUP & $\begin{array}{l}\text { (Vercellotti, et al., } \\
\text { 2008) }\end{array}$ & $\begin{array}{l}\text { (Fu, et al., 2016, } \\
\text { Villotte, 2009) }\end{array}$ \\
\hline Oberkassel & OK1 (M), OK2 (F) & Allemagne & LUP & Personal observation & (Trinkaus, 2015) \\
\hline
\end{tabular}

Table 2. Reference material: code, sex, localization, period, data source and sex source of the specimens. $*$ indicates the specimen is considered as of undetermined sex. 
To summarize, the MUP subsample includes 10 males, 6 females and 9 undetermined sex individuals; the LUP group is composed of 10 males, 5 females, and 6 undetermined sex individuals. The 15 subjects without assessed sex were not used in the sex-related tests.

\subsection{Statistical analysis of the cranium}

The morphometric variations in terms of size are related to sexual dimorphism, but the morphology also contains variations in shape that may be related to sex: applying a log correction to linear variables is a method commonly used to extract shape information (e.g. Churchill, et al. (1999)). We use size-adjusted measurements following the ratio for shape analysis (Jungers, et al., 1995), as proposed by Darroch and Mosimann (1985) to obtain the log shape ratios of the linear measurements. Including the linear variables, the indices, and the log shape ratios, a total of 78 variables are used to assess the position of L2A among the Upper Paleolithic (UP). As some variables do not follow a normal distribution, the nonparametric test was used (Wilcoxon-Mann-Whitney) to assess the cranial differences between groups on the measurements, indices, and log shape ratios. Principal Component Analyses (PCA) allow for a synthetization of the variables and help with the interpretation of the positioning of the L2A specimen within the comparative samples. Instead of replacing the missing values with the mean of variables (the default option in most software), we use the missMDA R package to perform more specific estimations of these unknown values following the subject's pattern (Josse and Husson, 2013). Additionally, probabilistic distances, or adjusted Z-scores (Maureille, et al., 2001), calculated between the means of the UP, MUP, and LUP samples and the variables from L2A will provide a visual assessment of its position relative to the comparative sample. Non-parametric tests were performed in Statistica $C$ (v. 7.1, StatSoftC), Tulsa, OK), and PCA with R (R Core Team, 2016).

\section{Results}

\subsection{DSP results}

The virtual analysis of the ossa coxarum allowed for the collection of additional data compared to the in situ preliminary study (one variable on the left os coxae and three new measurements on the right os coxae). The DSP results are displayed in Table 3.

\begin{tabular}{|c|c|c|c|c|c|c|c|c|c|c|c|c|c|c|}
\hline $\begin{array}{c}\text { Os } \\
\text { Coxae }\end{array}$ & Observation & PUM & SPU & DCOX & IIMT & ISMM & SCOX & SS & SA & SIS & VEAC & PF & PM & Sex \\
\hline \multirow{3}{*}{ Left } & Villotte et al. 2015, obs 1 & $\mathrm{n} / \mathrm{o}$ & 28.7 & 214.0 & 37.0 & $\mathrm{n} / \mathrm{o}$ & $\mathrm{n} / \mathrm{o}$ & 75.6 & 76.4 & $\mathrm{n} / \mathrm{o}$ & $\mathrm{n} / \mathrm{o}$ & 0.018 & 0.982 & Male \\
\cline { 2 - 13 } & Villotte et al. 2015, obs 2 & $\mathrm{n} / \mathrm{o}$ & 30.3 & 216.0 & 38.2 & $\mathrm{n} / \mathrm{o}$ & $\mathrm{n} / \mathrm{o}$ & 75.1 & 78.2 & $\mathrm{n} / \mathrm{o}$ & $\mathrm{n} / \mathrm{o}$ & 0.012 & 0.988 & Male \\
\cline { 2 - 13 } & 3D photogrammetry & $\mathrm{n} / \mathrm{o}$ & 29.4 & 216.9 & 38.4 & $\mathrm{n} / \mathrm{o}$ & 152.1 & 75.1 & 76.0 & $\mathrm{n} / \mathrm{o}$ & $\mathrm{n} / \mathrm{o}$ & 0.001 & 0.999 & Male \\
\hline \multirow{3}{*}{ Right } & Villotte et al. 2015, obs 1 & $\mathrm{n} / \mathrm{o}$ & $\mathrm{n} / \mathrm{o}$ & $\mathrm{n} / \mathrm{o}$ & $\mathrm{n} / \mathrm{o}$ & 100.0 & $\mathrm{n} / \mathrm{o}$ & $\mathrm{n} / \mathrm{o}$ & $\mathrm{n} / \mathrm{o}$ & 38.8 & 47.6 & $\mathrm{n} / \mathrm{a}$ & $\mathrm{n} / \mathrm{a}$ & $\mathrm{n} / \mathrm{a}$ \\
\cline { 2 - 13 } & Villotte et al. 2015, obs 2 & $\mathrm{n} / \mathrm{o}$ & $\mathrm{n} / \mathrm{o}$ & $\mathrm{n} / \mathrm{o}$ & $\mathrm{n} / \mathrm{o}$ & 103.5 & $\mathrm{n} / \mathrm{o}$ & $\mathrm{n} / \mathrm{o}$ & $\mathrm{n} / \mathrm{o}$ & 37.2 & 52.5 & $\mathrm{n} / \mathrm{a}$ & $\mathrm{n} / \mathrm{a}$ & $\mathrm{n} / \mathrm{a}$ \\
\cline { 2 - 12 } & 3D photogrammetry & $\mathrm{n} / \mathrm{o}$ & $\mathrm{n} / \mathrm{o}$ & $\mathrm{n} / \mathrm{o}$ & 39.4 & 106.7 & 155.9 & 74.8 & $\mathrm{n} / \mathrm{o}$ & 37.2 & 51.3 & 0.386 & 0.614 & ND \\
\hline
\end{tabular}

Table 3. DSP input and results for the left and right ossa coxarum, including the measurements collected in situ by two observers (Villotte, et al., 2015), and the measurements 
collected on the 3D photogrammetric records in TIVMI; $\mathrm{n} / \mathrm{o}=$ not observable, $\mathrm{n} / \mathrm{a}=$ not applicable; $\mathrm{PF}=$ probability of female sex; $\mathrm{PM}=$ probability of male sex. See Murail, et al. (2005) for measurements abbreviations.

The negligible differences between the in situ and photogrammetric measurements confirm the validity of the virtual application of the DSP method, with an average difference in the measurements of $2.4 \%$ (sd: $2.2 \%$, min: $0.01 \%$, max: $7.9 \%$ ). The result on the left os coxae is similar to the conclusions of Villotte, et al. (2015), but the DSP failed to attribute a sex using the dimensions of the right os coxae. Any combination of four available measurements provides a higher probability for the male sex, but never above the acceptable threshold of 0.95 .

\subsection{Craniometric results}

The visible cranial morphology of L2A is not particularly indicative of its sex, with some masculine (no frontal or parietal eminences, square orbits) and some feminine (V-shaped palate, smooth nuchal crests, small occipital condyles) traits displayed. The other commonly used features are either moderately expressed (mastoid process, supraorbital ridge) or not observable. A morphometric analysis was thus performed.

The 78 cranial variables were tested for significant differences between males and females with the Wilcoxon-Mann-Whitney test. Eleven variables show a significant sexual dimorphism in the UP sample (Supplementary Table 1), with males consistently displaying larger values than females. Overall, the values for L2A tend to indicate a relatively small size. This is illustrated by the PCA on the sexually dimorphic size variables (Figure 4). The first principal component (PC) of the size PCA (50.6\%) allows for a distinctive separation between sexes, and L2A is within the male variability (positive values), but also close to the female group (negative values). Regarding the PCA on sexually dimorphic shape variables, the first PC (65.2\%) shows a stronger overlap of the groups, and L2A is closer to the male variability (positive values) than the female one (negative values). A linear discriminant analysis computed on the sexually dimorphic variables (size and shape) classified L2A as male with a posterior probability of 0.97 (see Supplementary Data for details on the analysis). 


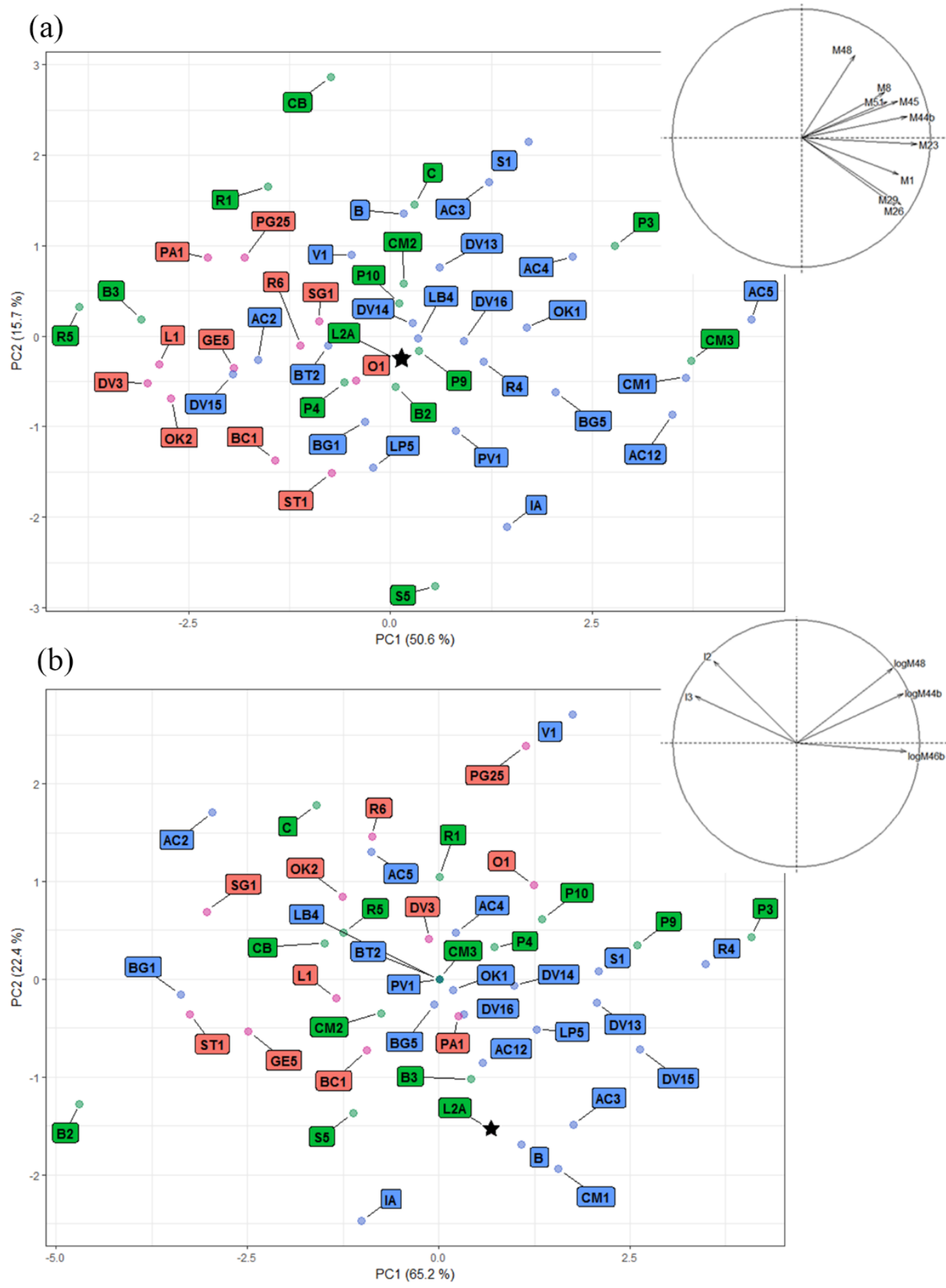

Figure 4. PCAs on sexually dimorphic size (a) and shape (b) variables (blue = males, red = females, undetermined sex $=$ green). L2A is indicated with a star. Dimorphic variables used are M1, M8, M23, M26, M45, M48 and M51 for size morphology, and I2, I3, logM44b, $\log \mathrm{M} 46 \mathrm{~b}$ and $\log \mathrm{M} 48$ for shape morphology. 
When considering the main cranial variables for which no sexual dimorphism was detected in the UP sample, L2A shows some very low (M17, M29, M52, M55) and very high (M44b, M54, M61) values, which are outside the range of variation known for the UP (Figure 5).

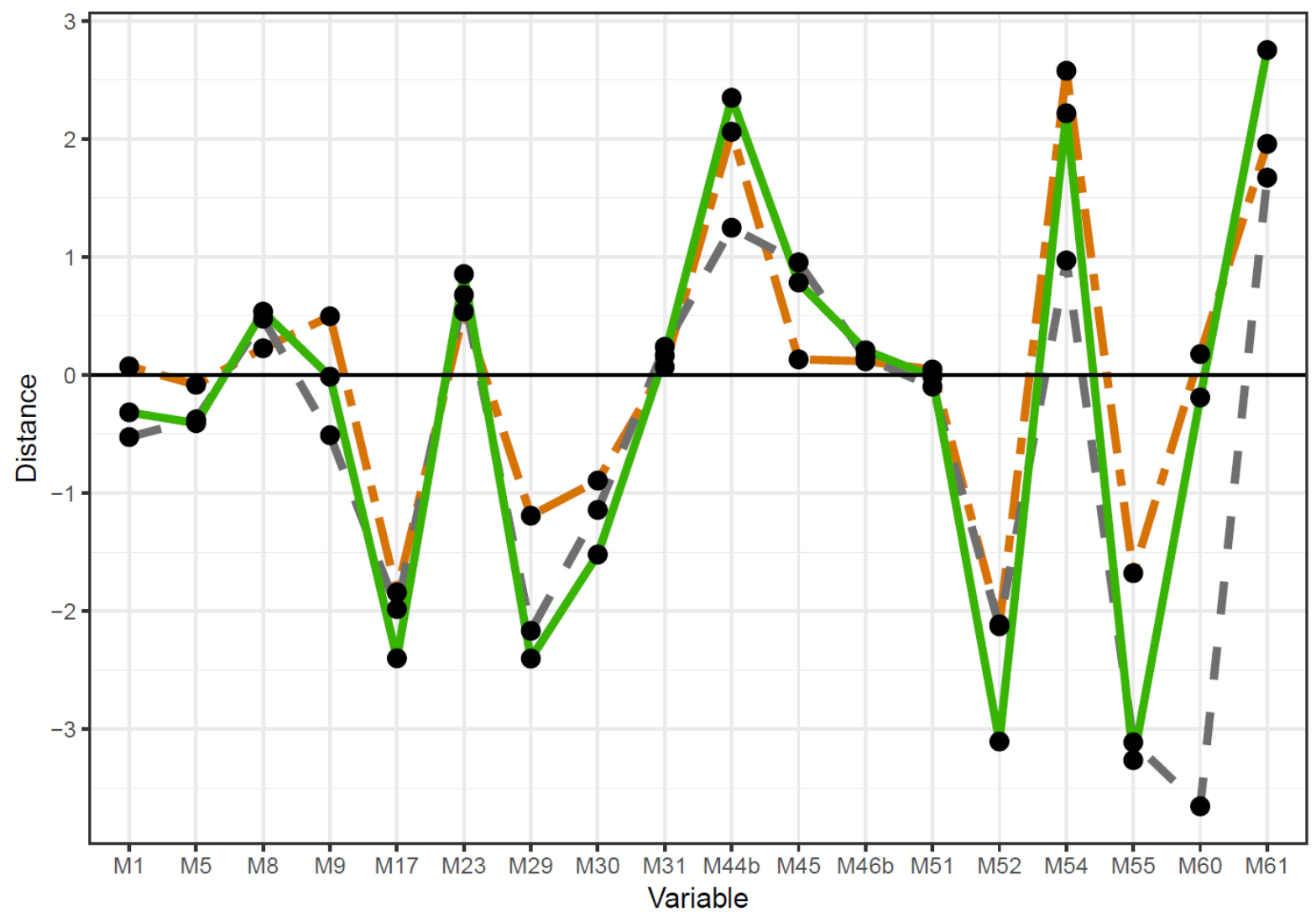

Figure 5. Adjusted Z-scores between L2A, and the UP (green line), MUP (gray dashed line), and LUP (orange double-dashed line) comparative samples, computed on main cranial variables. The values -1 and 1 on the y axis represent $95 \%$ of the group variabilities; the position of the groups is relative to the L2A measurements.

L2A thus presents a very peculiar morphology, with a relatively flattened cranium, a wide face, a wide and short nasal aperture, a wide palate, and low orbital height (e.g. Figure 6). To illustrate this peculiar cranial shape, a selection of indices was processed in a PCA (I1, I4, I5, I12, I13, I18, I39, I42, I48, I54); because the results displayed a wide variability, the three first PCs are presented in Figure 7. On PC1 and PC3, L2A appears relatively separated from the UP sample, although cannot be considered a clear outlier. 

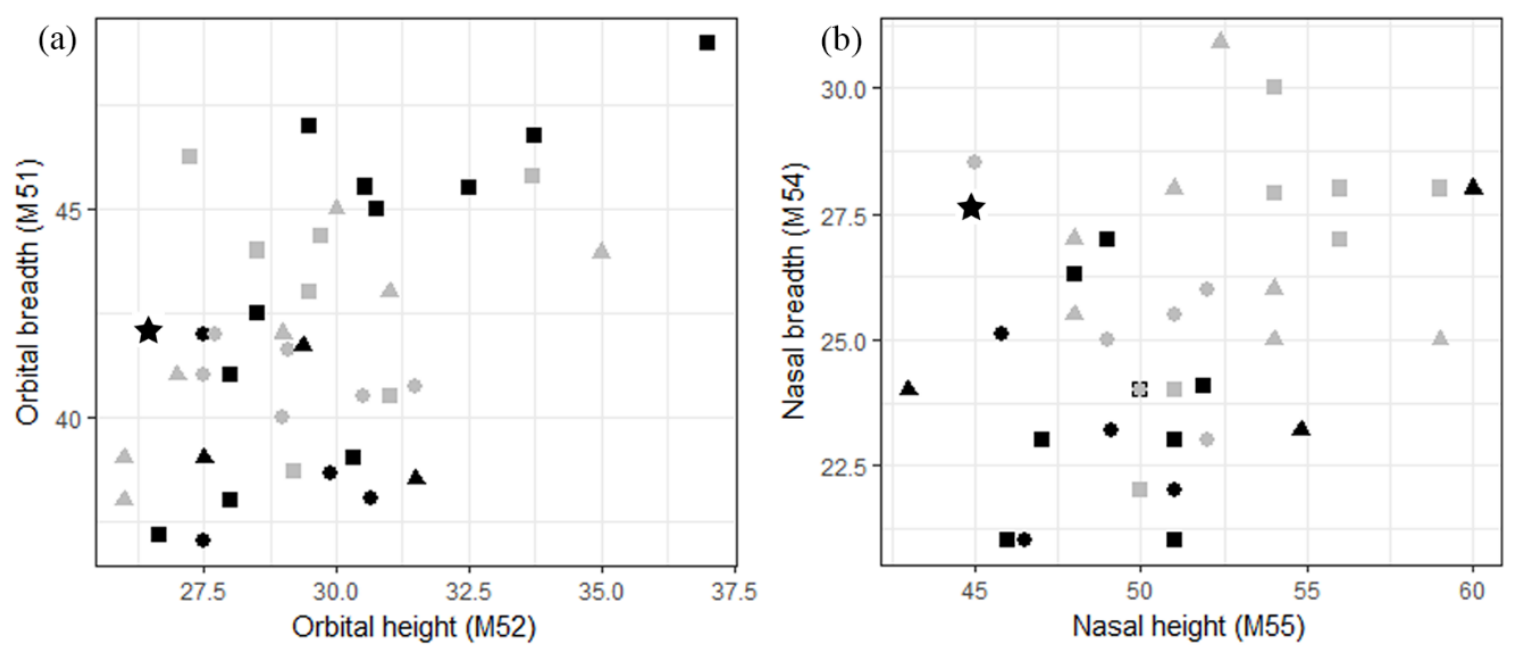

Figure 6. Bivariate plots for orbital (a) and nasal (b) height and breadth (in mm) in the UP sample $(\mathrm{MUP}=$ gray, $\mathrm{LUP}=$ black, male $=$ square, female $=$ circle, indeterminate $=$ triangle , $\mathrm{L} 2 \mathrm{~A}=$ star$)$.

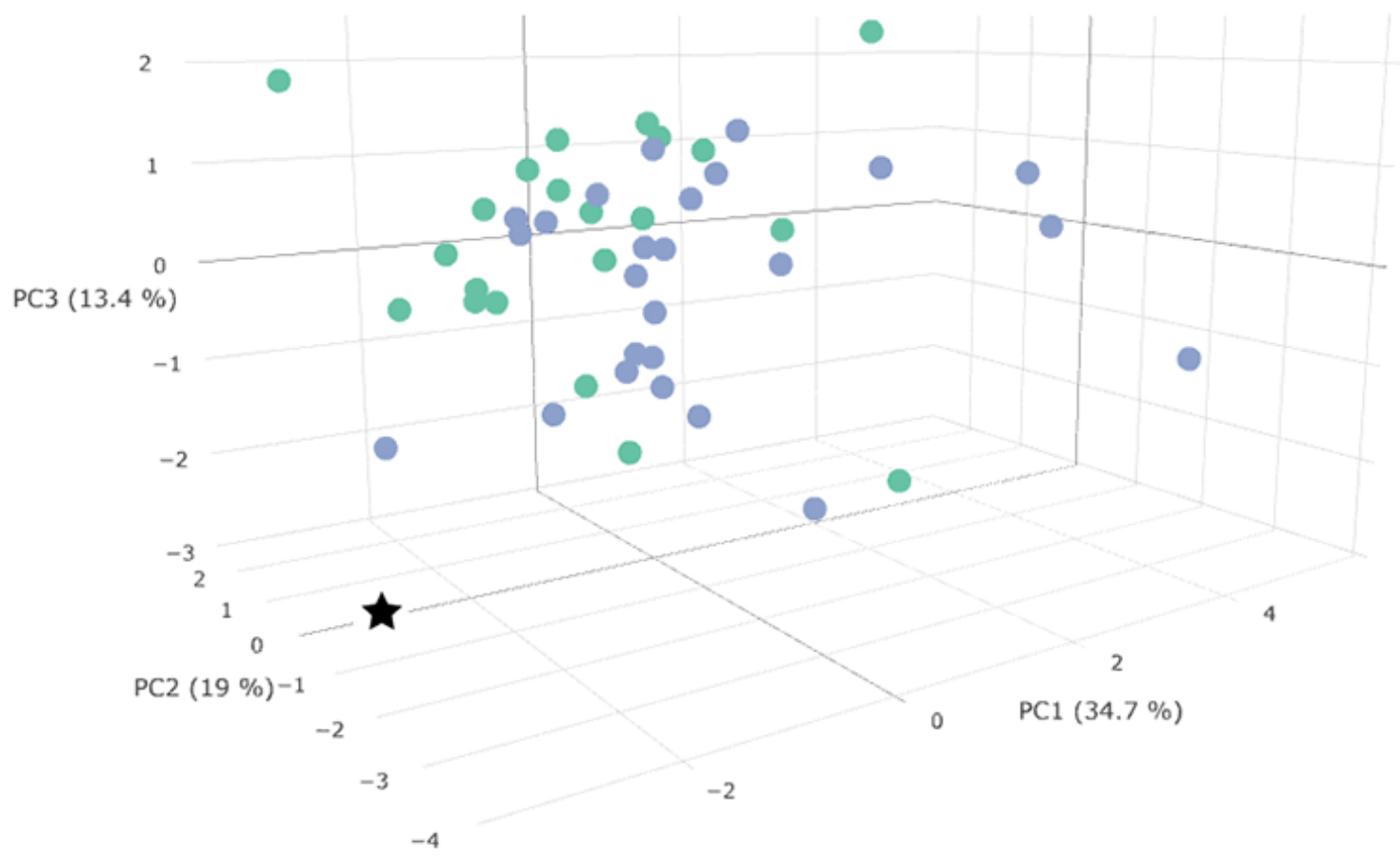

Figure 7. 3D scatterplot of PC1, PC2 and PC 3 of the PCA performed on 10 cranial indices (MUP = blue, LUP = green, L2A = star).

\section{Discussion and conclusions}

The extensive photogrammetric record of Cussac cave allowed for the reconstruction of 3D models that could be used for new bioanthropological study, while minimizing the manipulation of those protected human remains. New metric data were generated for the 
Gravettian individual L2A, allowing for further evaluation of the cranial and pelvic remains through a virtual anthropology approach (Weber and Bookstein, 2011).

Although this kind of virtual analysis cannot fully replace the traditional study of the remains (i.e. we have no access to the whole surface of the bones or their internal structures), our research confirmed a male sex diagnosis for L2A. Despite his relatively small-sized cranium, the presence of some female non-metric cranial features, and a short stature relative to other Upper Palaeolithic individuals, the pelvis clearly indicates a male sex. Several Upper Palaeolithic fossils were traditionally diagnosed solely from the cranial morphology (Gambier, et al., 2006, Villotte, et al., 2011), and following this method L2A may have been wrongly sexed as a female. The example of L2A highlights the risk of obtaining the wrong sex diagnosis using non-pelvic traits.

L2A's stature is well below the range of variation seen for Gravettian males, and its body proportions are uncommon for the Middle Upper Palaolithic, with the femur being rather long compared to the humerus and tibia (Villotte, et al., 2015). The peculiarity of this individuals is confirmed by the results of the present analysis, which show an unusual cranial morphology. L2A body proportions and cranial morphological peculiarities may be related to a growth delay, or a pathology. Congenital disorders are common in the Late Pleistocene human fossil record, and this has been interpreted as a possible indicator of high levels of inbreeding (Sparacello, et al., n.d., Wu, et al., 2013). L2A may be another case in support of this hypothesis. No definitive conclusion can be drawn without excavating the remains; however current evidence on cranial morphology and body proportions suggests that L2A can be considered as an outlier among the Gravettian variability.

The joint analysis of the biological profile of buried individuals and of their depositional context is essential for a proper interpretation of Paleolithic funerary behaviors (Mittnik, et al., 2016, Trinkaus and Svoboda, 2006). L2A's biological characteristics, in the specific context of Cussac, raise the question of the social status of this male individual. L2A is one of the few Upper Paleolithic subjects from the southwest of France discovered in relative anatomical connection (Henry-Gambier 2005, 2008), and although several flooding episodes are attested to the layer of clay covering most of its bones, their position strongly advocates for a primary deposit in ventral decubitus (Jaubert, et al., 2016), a very rare position for the Gravettian. Indeed, out of ca. 33 attested Gravettian burials (with ca. 100 individuals), only three other subjects are in a ventral position (BT3, GE5 in the Grotte des Enfants double burial, and DV14 in the triple burial of Dolní Věstonice) (Henry-Gambier, 2008, RielSalvatore and Gravel-Miguel, 2013). Moreover, very few Paleolithic human remains were found in a decorated cave or shelter (Bartolomei, et al., 1974, Foucher, et al., 2012, HenryGambier, et al., 2007, Mallegni and Fabbri, 1995, Mussi, et al., 2008). The body position of L2A, the fact that the body was deposited in a decorated cave, and its peculiar morphology echo with other UP burials displaying an association between a specific funerary treatment and marked osseous modifications, i.e. the burials of Dolní Věstonice, Sunghir, Arene Candide, and Romito sites (Formicola, 2007, Formicola, et al., 2001, Mallegni and Fabbri, 1995, Sparacello, et al., n.d., Trinkaus, et al., 2014). 
The continuation of the biological analyses of the Cussac human remains - in particular the infracranial skeleton of L2A in the event of new excavation of the Locus 2 in the near future as well as their integration with data from other scientific disciplines, will deepen our understanding of the Gravettian funerary practices in the southwest of France. The analysis (and reanalysis) of the other skeletal remains from this region will also be necessary. A laboratory study of these remains is essential to bridge the gaps in our knowledge about the biological variability during the Gravettian, and its possible relations with funerary behavior, which is still poorly documented. 


\section{Acknowledgements}

Authors would like to acknowledge Vitale Stefano Sparacello for sharing additional data, providing insights on this study, and for a thorough editing of the paper, as well as Frédéric Santos for statistical support. We are grateful to the following institutions, curators and researchers that provided MS access to their facilities and granted her permission to examine the palaeoanthropological material in their care: Institut de Paléontologie Humaine (H. de Lumley), Museo Geologico G. G. Gemmellaro di Palermo (C. di Patti), Musée d'Archéologie Nationale (C. Schwab), Musée National de Préhistoire (J.-J.- Cleyet-Merle), Musée d'Archéologie Tricastine (M. Lert) and Service Régional d'Archéologie Auvergne-RhôneAlpes (P. Chapuis), Musée d'Art et d'Archéologie du Périgord, Périgueux (V. MerlinAnglade), Musée Labenche d'Art et d'Histoire, Brive (L. Michelin), Museum d'Histoire Naturelle Victor Brun, Montauban (A. Bergeret), R. W. Schmitz (LVR_LandesMuseum Bonn) and J. J. Hublin (Department of Human Evolution Max Planck Institute for Evolutionary Anthropology, Leipzig). Authors are also thankful for the Cussac Programme Commun de Recherche for their productive teamwork on this exceptional site. 


\section{Supplementary Data}

The following Supplementary Table 1 contains the descriptive statistics of the comparative sample $(n=46)$ and the raw values for the subject L2A.

\begin{tabular}{|c|c|c|c|c|c|c|c|c|c|c|c|c|c|c|}
\hline & \multicolumn{3}{|c|}{ MUP } & \multicolumn{3}{|c|}{ LUP } & \multicolumn{3}{|c|}{ Males } & \multicolumn{3}{|c|}{ Females } & \multirow{2}{*}{$p(\operatorname{sex})$} & \multirow{2}{*}{ L2A } \\
\hline & $\mathrm{n}$ & mean & sd & $n$ & mean & sd & $\mathrm{n}$ & mean & $s d$ & $\mathrm{n}$ & mean & sd & & \\
\hline M1 & 25 & 193.3 & 7.1 & 21 & 190.8 & 8.1 & 22 & 194.1 & 7.7 & 11 & 188.5 & 6.9 & 0.05 & 191.1 \\
\hline M2 & 16 & 188.6 & 8.1 & 17 & 182.7 & 7.2 & 19 & 187.0 & 8.3 & 7 & 182.0 & 6.2 & 0.09 & 179.7 \\
\hline M3 & 20 & 187.3 & 7.0 & 11 & 183.6 & 4.2 & 12 & 189.2 & 5.7 & 8 & 183.2 & 5.2 & 0.07 & 179.9 \\
\hline M5 & 8 & \begin{tabular}{|l|}
108.1 \\
\end{tabular} & 18.6 & 19 & \begin{tabular}{|l|}
100.3 \\
\end{tabular} & 7.4 & 16 & 102.7 & 15.0 & 7 & 100.9 & 4.6 & 0.87 & 98.6 \\
\hline M8 & 25 & 138.9 & 5.7 & 20 & 139.8 & 4.7 & 21 & 140.7 & 4.5 & 11 & 135.8 & 4.4 & 0.01 & 140.5 \\
\hline M9 & 24 & 99.7 & 5.0 & 21 & 96.5 & 5.2 & 21 & 99.5 & 5.4 & 11 & 96.0 & 3.6 & 0.05 & 98.2 \\
\hline M10 & 22 & \begin{tabular}{|l}
120.2 \\
\end{tabular} & 5.9 & 18 & 115.9 & 5.4 & 19 & 119.5 & 5.8 & 10 & 116.3 & 4.0 & 0.15 & 125.9 \\
\hline M17 & 14 & 133.2 & 2.5 & 18 & 136.7 & 5.9 & 15 & 134.9 & 5.8 & 9 & 134.8 & 4.6 & 0.86 & 129.1 \\
\hline M20 & 17 & 118.6 & 7.6 & 18 & 114.2 & 4.3 & 17 & 117.3 & 7.2 & 9 & 115.2 & 4.3 & 0.43 & 108.0 \\
\hline M23 & 8 & 538.8 & 16.9 & 17 & 543.4 & 22.7 & 12 & 553.4 & 20.5 & 7 & 529.3 & 11.5 & 0.01 & 552.3 \\
\hline M24 & 8 & 319.6 & 11.7 & 9 & 309.4 & 15.9 & 7 & 318.6 & 11.0 & 6 & 314.8 & 11.2 & 0.37 & 154.9 \\
\hline M26 & 19 & 135.6 & 8.6 & 17 & 132.3 & 8.0 & 20 & 136.7 & 6.5 & 8 & 129.8 & 3.9 & 0.02 & 129.5 \\
\hline M27 & 19 & 131.8 & 8.9 & 16 & 137.2 & 10.1 & 19 & 134.7 & 10.4 & 8 & 135.4 & 9.6 & 0.70 & 127.1 \\
\hline M28 & 11 & 123.0 & 5.2 & 14 & 118.6 & 10.9 & 14 & 121.4 & 8.3 & 7 & 121.5 & 11.4 & 0.86 & 131.0 \\
\hline M29 & 19 & 117.6 & 6.2 & 17 & 113.6 & 6.0 & 20 & 117.7 & 4.7 & 8 & 111.4 & 5.0 & 0.01 & 109.6 \\
\hline M30 & 23 & 120.0 & 7.9 & 16 & 120.2 & 8.5 & 19 & 121.4 & 7.9 & 8 & 119.3 & 6.6 & 0.77 & 114.5 \\
\hline M31 & 10 & 99.7 & 3.8 & 13 & 100.1 & 8.6 & 14 & 100.1 & 7.6 & 7 & 99.6 & 6.6 & 0.86 & 100.6 \\
\hline M40 & 8 & 103.1 & 4.1 & 15 & 96.2 & 6.9 & 14 & 97.9 & 7.6 & 5 & 97.6 & 7.1 & 1.00 & 99.5 \\
\hline M44b & 13 & 100.2 & 4.6 & 16 & 95.5 & 6.2 & 16 & 100.9 & 4.3 & 8 & 92.6 & 5.7 & $<0.01$ & 105.1 \\
\hline M45 & 15 & 134.2 & 7.7 & 15 & 139.1 & 7.5 & 13 & 142.4 & 5.0 & 9 & 130.1 & 5.1 & $<0.01$ & 139.9 \\
\hline M46b & 11 & 96.3 & 7.7 & 8 & 96.1 & 9.0 & 10 & 99.0 & 5.3 & 6 & 89.4 & 9.7 & 0.07 & 97.4 \\
\hline M48 & 20 & 67.5 & 4.8 & 17 & 67.3 & 4.5 & 17 & 68.0 & 3.8 & 10 & 64.5 & 2.1 & $<0.01$ & 60.3 \\
\hline M51 & 20 & 42.0 & 2.4 & 18 & 41.7 & 3.9 & 18 & 43.3 & 3.5 & 10 & 40.2 & 1.7 & 0.02 & 41.9 \\
\hline M52 & 22 & 29.7 & 2.4 & 20 & 30.4 & 2.8 & 20 & 30.3 & 2.5 & 11 & 29.7 & 2.5 & 0.38 & 26.4 \\
\hline M54 & 21 & 26.3 & 2.2 & 18 & 23.8 & 2.2 & 17 & 24.9 & 2.8 & 11 & 24.6 & 2.2 & 0.78 & 27.7 \\
\hline M55 & 20 & 52.3 & 3.6 & 19 & 49.3 & 3.9 & 18 & 50.9 & 3.8 & 11 & 49.1 & 2.4 & 0.28 & 42.3 \\
\hline M60 & 8 & 55.8 & 0.7 & 14 & 51.9 & 5.7 & 14 & 54.6 & 3.9 & 6 & 51.5 & 6.8 & 0.78 & 52.7 \\
\hline M61 & 11 & 62.0 & 5.1 & 16 & 61.5 & 5.9 & 16 & 62.1 & 6.0 & 8 & 61.4 & 5.0 & 0.53 & 70.2 \\
\hline M62 & 3 & 48.3 & 2.9 & 11 & 44.3 & 4.9 & 8 & 45.0 & 3.3 & 4 & 47.8 & 6.2 & 0.46 & 45.9 \\
\hline M63 & 11 & 36.7 & 3.7 & 14 & 37.3 & 1.6 & 14 & 37.8 & 2.6 & 7 & 36.1 & 3.1 & 0.22 & 39.0 \\
\hline 11 & 25 & 71.9 & 3.4 & 20 & 73.4 & 2.8 & 21 & 72.6 & 3.1 & 11 & 72.1 & 3.5 & 0.70 & 73.5 \\
\hline 12 & 14 & 69.2 & 2.2 & 18 & 71.6 & 3.2 & 15 & 69.5 & 3.2 & 9 & 71.8 & 1.7 & 0.01 & 67.5 \\
\hline 13 & 14 & 95.7 & 4.4 & 17 & 97.9 & 5.0 & 14 & 94.5 & 4.8 & 9 & 99.9 & 3.2 & 0.01 & 91.9 \\
\hline 14 & 17 & 61.7 & 3.0 & 18 & 59.8 & 2.3 & 17 & 60.4 & 3.4 & 9 & 61.1 & 2.2 & 0.29 & 56.5 \\
\hline 15 & 17 & 86.0 & 6.5 & 17 & 81.8 & 3.5 & 16 & 83.1 & 6.1 & 9 & 84.8 & 4.4 & 0.12 & 76.9 \\
\hline 112 & 22 & 82.7 & 3.0 & 18 & 83.5 & 3.6 & 19 & 83.6 & 3.1 & 10 & 82.8 & 3.0 & 0.46 & 78.0 \\
\hline 113 & 24 & 71.8 & 3.9 & 20 & 69.0 & 3.5 & 20 & 70.7 & 4.4 & 11 & 70.7 & 2.6 & 0.70 & 69.9 \\
\hline 116 & 19 & 97.5 & 7.6 & 16 & 104.7 & 9.4 & 19 & 99.2 & 9.5 & 8 & \begin{tabular}{|l}
104.3 \\
\end{tabular} & 6.9 & 0.12 & 98.2 \\
\hline 117 & 11 & 90.9 & 6.7 & 14 & 90.6 & 8.2 & 14 & 89.5 & 6.4 & 7 & 93.9 & 8.4 & 0.40 & 101.2 \\
\hline I18 & 11 & 94.9 & 5.4 & 14 & 86.5 & 10.7 & 14 & 90.7 & 9.2 & 7 & 90.6 & 12.6 & 0.86 & 103.1 \\
\hline 122 & 19 & 86.8 & 2.8 & 17 & 86.0 & 3.5 & 20 & 86.2 & 2.9 & 8 & 85.9 & 4.4 & 0.86 & 84.7 \\
\hline 124 & 19 & 91.6 & 2.9 & 16 & 87.7 & 3.6 & 19 & 90.3 & 2.8 & 8 & 88.2 & 3.8 & 0.39 & 90.1 \\
\hline 139 & 15 & 50.7 & 2.7 & 14 & 48.2 & 3.6 & 13 & 48.1 & 3.4 & 9 & 50.0 & 2.2 & 0.21 & 43.1 \\
\hline 142 & 20 & 70.1 & 5.1 & 18 & 72.0 & 5.2 & 18 & 70.0 & 5.1 & 10 & 72.6 & 5.3 & 0.29 & 63.1 \\
\hline 142(1) & 14 & 31.3 & 2.4 & 13 & 30.2 & 2.5 & 12 & 30.8 & 2.4 & 8 & 31.4 & 2.1 & 0.73 & 29.9 \\
\hline 142(2) & 20 & 43.8 & 4.7 & 16 & 45.6 & 4.5 & 17 & 44.6 & 3.6 & 10 & 46.0 & 4.6 & 0.54 & 43.8 \\
\hline 148 & 20 & 50.5 & 5.3 & 17 & 48.2 & 5.0 & 16 & 48.3 & 4.2 & 11 & 50.2 & 5.9 & 0.48 & 65.4 \\
\hline 154 & 8 & 111.5 & 9.3 & 13 & 121.0 & 21.9 & 13 & 115.4 & 16.6 & 6 & 122.2 & 25.2 & 0.90 & 133.2 \\
\hline logM1 & 25 & 0.29 & 0.07 & 21 & 0.3 & 0.05 & 22 & 0.29 & 0.06 & 11 & 0.31 & 0.04 & 0.61 & 0.30 \\
\hline logM2 & 16 & 0.25 & 0.08 & 17 & 0.27 & 0.05 & 19 & 0.27 & 0.06 & 7 & 0.29 & 0.03 & 0.82 & 0.27 \\
\hline $\log 33$ & 20 & 0.28 & 0.07 & 11 & 0.26 & 0.05 & 12 & 0.27 & 0.06 & 8 & 0.28 & 0.03 & 0.97 & 0.28 \\
\hline logM5 & 8 & 0.03 & 0.05 & 19 & 0.03 & 0.04 & 16 & 0.02 & 0.04 & 7 & 0.04 & 0.03 & 0.72 & 0.01 \\
\hline logM8 & 25 & 0.15 & 0.08 & 20 & 0.16 & 0.05 & 21 & 0.15 & 0.07 & 11 & 0.17 & 0.05 & 0.94 & 0.17 \\
\hline logM9 & 24 & 0.01 & 0.08 & 21 & 0.00 & 0.05 & 21 & 0.01 & 0.06 & 11 & 0.02 & 0.05 & 0.97 & 0.01 \\
\hline
\end{tabular}




\begin{tabular}{|c|c|c|c|c|c|c|c|c|c|c|c|c|c|c|}
\hline $\log \mathrm{M} 10$ & 22 & 0.09 & 0.07 & 18 & 0.07 & 0.05 & 19 & 0.08 & 0.05 & 10 & 0.1 & 0.06 & 0.84 & 0.12 \\
\hline $\log M 17$ & 14 & 0.16 & 0.04 & 18 & 0.16 & 0.04 & 15 & 0.16 & 0.04 & 9 & 0.17 & 0.04 & 0.38 & 0.13 \\
\hline $\log M 20$ & 17 & 0.07 & 0.06 & 18 & 0.08 & 0.05 & 17 & 0.06 & 0.07 & 9 & 0.09 & 0.05 & 0.43 & 0.05 \\
\hline $\log M 23$ & 8 & 0.69 & 0.07 & 17 & 0.74 & 0.05 & 12 & 0.74 & 0.06 & 7 & 0.73 & 0.03 & 0.54 & 0.76 \\
\hline logM24 & 8 & 0.49 & 0.03 & 9 & 0.48 & 0.05 & 7 & 0.47 & 0.05 & 6 & 0.5 & 0.02 & 0.45 & 0.21 \\
\hline $\log M 26$ & 19 & 0.11 & 0.07 & 17 & 0.13 & 0.05 & 20 & 0.13 & 0.06 & 8 & 0.13 & 0.03 & 0.67 & 0.13 \\
\hline $\log M 27$ & 19 & 0.10 & 0.08 & 16 & 0.14 & 0.06 & 19 & 0.12 & 0.07 & 8 & 0.15 & 0.05 & 0.58 & 0.12 \\
\hline $\log M 28$ & 11 & 0.10 & 0.04 & 14 & 0.08 & 0.05 & 14 & 0.09 & 0.04 & 7 & 0.1 & 0.04 & 0.69 & 0.14 \\
\hline logM29 & 19 & 0.05 & 0.07 & 17 & 0.06 & 0.05 & 20 & 0.06 & 0.06 & 8 & 0.06 & 0.02 & 0.41 & 0.06 \\
\hline $\log \mathrm{M} 30$ & 23 & 0.08 & 0.08 & 16 & 0.08 & 0.06 & 19 & 0.08 & 0.07 & 8 & 0.09 & 0.04 & 0.98 & 0.08 \\
\hline $\log M 31$ & 10 & 0.01 & 0.04 & 13 & 0.01 & 0.05 & 14 & 0.01 & 0.05 & 7 & 0.02 & 0.03 & 0.64 & 0.02 \\
\hline $\log M 40$ & 8 & 0.04 & 0.04 & 15 & 0.00 & 0.04 & 14 & 0.02 & 0.04 & 5 & 0.01 & 0.05 & 1.00 & 0.02 \\
\hline $\log M 44 b$ & 13 & 0.01 & 0.05 & 16 & 0.01 & 0.04 & 16 & 0.02 & 0.03 & 8 & -0.01 & 0.04 & 0.07 & 0.04 \\
\hline $\log M 45$ & 15 & 0.16 & 0.05 & 15 & 0.17 & 0.05 & 13 & 0.18 & 0.04 & 9 & 0.15 & 0.06 & 0.32 & 0.17 \\
\hline logM46b & 11 & 0.00 & 0.03 & 8 & -0.01 & 0.05 & 10 & 0.01 & 0.03 & 6 & -0.03 & 0.04 & 0.09 & 0.01 \\
\hline $\log M 48$ & 20 & -0.14 & 0.05 & 17 & -0.15 & 0.05 & 17 & -0.14 & 0.05 & 10 & -0.16 & 0.05 & 0.22 & -0.20 \\
\hline logM51 & 20 & -0.35 & 0.04 & 18 & -0.35 & 0.06 & 18 & -0.34 & 0.06 & 10 & -0.36 & 0.05 & 0.31 & -0.36 \\
\hline logM52 & 22 & -0.5 & 0.05 & 20 & -0.5 & 0.05 & 20 & -0.5 & 0.06 & 11 & -0.49 & 0.05 & 0.79 & -0.56 \\
\hline $\log M 54$ & 21 & -0.55 & 0.05 & 18 & -0.6 & 0.06 & 17 & -0.58 & 0.06 & 11 & -0.57 & 0.06 & 0.78 & -0.54 \\
\hline logM55 & 20 & -0.25 & 0.05 & 19 & -0.28 & 0.05 & 18 & -0.26 & 0.05 & 11 & -0.27 & 0.06 & 0.61 & -0.35 \\
\hline $\log M 60$ & 8 & -0.23 & 0.03 & 14 & -0.27 & 0.08 & 14 & -0.24 & 0.07 & 6 & -0.27 & 0.08 & 0.72 & -0.26 \\
\hline logM61 & 11 & -0.19 & 0.04 & 16 & -0.18 & 0.04 & 16 & -0.18 & 0.04 & 8 & -0.18 & 0.03 & 0.83 & -0.13 \\
\hline $\log M 62$ & 3 & -0.29 & 0.05 & 11 & -0.33 & 0.04 & 8 & -0.32 & 0.02 & 4 & -0.29 & 0.06 & 0.81 & -0.32 \\
\hline logM63 & 11 & -0.42 & 0.05 & 14 & -0.41 & 0.04 & 14 & -0.4 & 0.04 & 7 & -0.42 & 0.03 & 0.40 & -0.39 \\
\hline
\end{tabular}

Supplementary Table 1. Descriptive statistics for the MUP and LUP groups and results of the Wilcoxon-Mann-Whitney test on linear distances, indices, and log shape ratios (log) with mean, standard deviations (sd), and sample size (n). The adjusted p level is reported with a significant level inferior to 0.05 (in bold). The raw values ( $\mathrm{mm}$ for the linear variables) of Cussac L2A are reported for comparison.

The Supplementary Table 2 presents the specificities of a Linear Discriminant Analysis (LDA) based on dimorphic size and shape variables.

\begin{tabular}{|l|c|}
\hline & LDA \\
\hline Wilk's lambda & 0.28 \\
\hline Classification for males (at $\mathrm{pp}>0,50)$ & $100 \%(22 / 22)$ \\
\hline Classification for females (at $\mathrm{pp}>0,50)$ & $100 \%(11 / 11)$ \\
\hline Classification for males (at $\mathrm{pp}>0,90)$ & $(19 / 22)$ (no misclassification) \\
\hline Classification for females (at $\mathrm{pp}>0,90)$ & $(9 / 11)$ (no misclassification) \\
\hline
\end{tabular}

Supplementary Table 2. Results of the LDA. Prior probabilities are equal for each group. Missing values were replaced by MDA.

Using this model, individuals with an undetermined sex where classified as male for P10, P3, $\mathrm{C}$, and CM3; were classified as female RR1, R5, and B3; six subjects remained undetermined under the posterior probability of 0.90 : CM2, P3, P4, B2, S5, and CB. These results indicate a trend in the morphology of this sub-sample of MUP individual, and are globally consistent with the sexual diagnosis based on the cranial remains of these individuals. However, due to the small sample size and the varying sexual dimorphism of the skull, such model cannot be considered per se as a reliable sex determination method. 


\section{References}

Aujoulat, N., Geneste, J.-M., Archambeau, C., Delluc, M., Duday, H., Gambier, D., 2001. La grotte ornée de Cussac (Dordogne). Observations liminaires, PALEO 13.

Bartolomei, G., Broglio, A., Guerreschi, A., Leonardi, P., Peretto, C., Sala, B., 1974. Una sepoltura epigravettiana nel deposito pleistocenico del Riparo Tagliente in Valpantena (Verona), Rivista di Scienze Preistoriche, 101-152.

Billy, G., 1975. Etude anthropologique des restes humains de l'Abri Pataud, in: Movius, H.L.J. (Ed.), Excavation of the Abri Pataud. Les Eyzies (Dordogne), Harvard University, Peabody Museum, American School of Prehistoric Research, Cambridge, pp. 201-261.

Bräuer, G., 1988. Osteometrie, in: Knußman, R. (Ed.), Anthropologie, Band I: Wesen und Methoden de Anthropologie, volume 1: Wissenschafttheorie, Geschichte, morphologische Methoden, Gustav Fischer Verlag, Stuttgart, pp. 160-231.

Brůžek, J., 2002. A method for visual determination of sex, using the human hip bone, American Journal of Physical Anthropology 117, 157-168.

Chapman, T., Lefevre, P., Semal, P., Moiseev, F., Sholukha, V., Louryan, S., Rooze, M., Van Sint Jan, S., 2014. Sex determination using the Probabilistic Sex Diagnosis (DSP: Diagnose Sexuelle Probabiliste) tool in a virtual environment, Forensic science international 234, 189.e181-188.

Chauvière, F.-X., 2008. La grotte du Bichon : un site préhistorique des montagnes neuchâteloises, Archéologie neuchâteloise.

Churchill, S.E., Formicola, V., Holliday, T.W., Holt, B.M., Schumann, B.A., 1999. The Upper Paleolithic population of Europe in an evolutionary perspective, in: Svoboda, J., Roebroeks, W., Mussi, M., Soffer, O., Clottes, J., Larsson, L., Hahn, J., Bosinski, G., Zilhão, J., Montet-White, A., Corbey, R., Perlès, C., Pettitt, P., Djindjian, F., Iakovleva, L., Rigaud, J.-P., Vasil'ev, S.A., Taborin, Y. (Eds.), Hunters of the Golden Age, University of Leiden, Leiden, p. 410.

Coppola, D., 2013. Il Riparo di Agnano nel Paleolitico superiore - La sepoltura Ostuni 1 ed i suoi simboli, Terra, Universita di Roma Tor Vergata.

Darroch, J.N., Mosimann, J.E., 1985. Canonical and principal components of shape, Biometrika 72, 241-252.

De Lumley, H., 2016. La grotte du Cavillon sous les falaises des Baousse Rousse, Grimaldi, Vintimille, Italie, CNRS éditions, Paris.

Dutailly, B., 2016. TIVMI, Treatment and Increased Vision for Medical Imaging, 2.1 ed., Université de Bordeaux.

Ferrier, C., Konik, S., Ballade, M., Bourdier, C., Chapoulie, R., Feruglio, V., Queffelec, A., Jaubert, J., 2016. Cussac Cave (Dordogne, France): The role of the rock support in the parietal art distribution, technical choices, and intentional and unintentional marks on the cave walls, Quaternary International accepted, in press.

Formicola, V., 2007. From the Sunghir Children to the Romito Dwarf: Aspects of the Upper Paleolithic Funerary Landscape, The University of Chicago Press, p. 446. 
Formicola, V., Frayer, D.W., Heller, J.A., 1990. Bilateral absence of the lesser trochanter in a Late Epigravettian skeleton from Arene Candide (Italy), American journal of physical anthropology 83, 425-437.

Formicola, V., Pontrandolfi, A., Svoboda, J., 2001. The Upper Paleolithic triple burial of Dolní Věstonice: pathology and funerary behavior, Am J Phys Anthropol 115, 372-379.

Foucher, P., San Juan-Foucher, C., Henri-Gambier, D., Vercoutère, C., Ferrier, C., 2012. Découverte de la mandibule d'un jeune enfant dans un niveau gravettien de la grotte de Gargas (Hautes-Pyrénées, France), Paléo 23.

Fu, Q., Posth, C., Hajdinjak, M., Petr, M., Mallick, S., Fernandes, D., Furtwängler, A., Haak, W., Meyer, M., Mittnik, A., Nickel, B., Peltzer, A., Rohland, N., Slon, V., Talamo, S., Lazaridis, I., Lipson, M., Mathieson, I., Schiffels, S., Skoglund, P., Derevianko, A.P., Drozdov, N., Slavinsky, V., Tsybankov, A., Cremonesi, R.G., Mallegni, F., Gély, B., Vacca, E., Morales, M.R.G., Straus, L.G., Neugebauer-Maresch, C., Teschler-Nicola, M., Constantin, S., Moldovan, O.T., Benazzi, S., Peresani, M., Coppola, D., Lari, M., Ricci, S., Ronchitelli, A., Valentin, F., Thevenet, C., Wehrberger, K., Grigorescu, D., Rougier, H., Crevecoeur, I., Flas, D., Semal, P., Mannino, M.A., Cupillard, C., Bocherens, H., Conard, N.J., Harvati, K., Moiseyev, V., Drucker, D.G., Svoboda, J., Richards, M.P., Caramelli, D., Pinhasi, R., Kelso, J., Patterson, N., Krause, J., Pääbo, S., Reich, D., 2016. The genetic history of Ice Age Europe, Nature 534, 200-205.

Furukawa, Y., Ponce, J., 2010. Accurate, Dense, and Robust Multi-View Stereopsis, IEEE Trans. on Pattern Analysis and Machine Intelligence 32, 1362-1376.

Gambier, D., Brůžek, J., Schmitt, A., Houët, F., Murail, P., 2006. Révision du sexe et de l'âge au décès des fossiles de Cro-Magnon (Dordogne, France) à partir de l'os coxal, Comptes Rendus Palevol 5, 735-741.

Graziosi, P., 1942. L'uomo fossile della Barma Grande ai Balzi Rossi nel Museo di Mentone, Archivio per l'Anthropologia e l'Etnologia 62, 1-30.

Guipert, G., de Lumley, H., de Lumley, M.-A., 2014. Reconstruction du crâne de Barma del Caviglione 1 (Dame du Cavillon), Baoussé-Roussé, Grottes de Grimaldi, Annali dell'Université di Ferrara, Museologia Scientifica e Naturalistica 10, 239-244.

Guyomarc'h, P., Dutailly, B., Charton, J., Santos, F., Desbarats, P., Coqueugniot, H., 2014. Anthropological Facial Approximation in Three Dimensions (AFA3D): Computer-Assisted Estimation of the Facial Morphology Using Geometric Morphometrics, Journal of forensic sciences 59, 1502-1516.

Henry-Gambier, D., 2005. Les populations européennes du Paléolithique supérieur, in: Dutour, O., Hublin, J.-J., Vandermeersch, B. (Eds.), Origine et évolution des populations humaines, Comité des Travaux Historiques et Scientifiques, Paris, pp. 151-176.

Henry-Gambier, D., 2008. Comportement des populations d'Europe au Gravettien : pratiques funéraires et interprétations, Paléo, Revue d'Archéologie Préhistorique 20, 399-438.

Henry-Gambier, D., Beauval, C., Airvaux, J., Aujoulat, N., Baratin, J.F., Buisson-Catil, J., 2007. New hominid remains associated with Gravettian parietal art (Les Garennes, Vilhonneur, France), Journal of human evolution 53, 747-750. 
Henry-Gambier, D., Brůžek, J., Murail, P., Houët, F., 2002. Révision du sexe du squelette magdalénien de Saint-Germain-la-Riviere (Gironde, France), PALEO. Revue d'archéologie préhistorique, 205-212.

Henry-Gambier, D., Courtaud, P., Duday, H., Dutailly, B., Villotte, S., Deguilloux, M.-F., Pémonge, M.-H., Aujoulat, N., Delluc, M., Fourment, N., Jaubert, J., 2013. Grotte de Cussac (Le Buisson-de-Cadouin, Dordogne) : un exemple de comportement original pour le Gravettien, in: Jaubert, J., Fourment, N., Depaepe, P. (Eds.), Transitions, Ruptures et Continuité en Préhistoire : XXVIIe Congrès Préhistorique de France, Bordeaux - Les Eyzies 31 mai-5 juin 2010, pp. 169-182.

Jaubert, J., Genty, D., Valladas, H., Camus, H., Courtaud, P., Ferrier, C., Feruglio, V., Fourment, N., Konik, S., Villotte, S., Bourdier, C., Costamagno, S., Delluc, M., Goutas, N., Katnecker, É., Klaric, L., Langlais, M., Ledoux, L., Maksud, F., O'Farrell, M., Mallye, J.-B., Pierre, M., Pons-Branchu, E., Régnier, É., Théry-Parisot, I., 2016. The chronology of human and animal presence in the decorated and sepulchral cave of Cussac (France), Quaternary International.

Josse, J., Husson, F., 2013. Handling missing values in exploratory multivariate data analysis methods, Journal de la SFDS 153, 79-99.

Jungers, W.L., Falsetti, A.B., Wall, C.E., 1995. Shape, relative size, and size-adjustments in morphometrics, American Journal of Physical Anthropology 38, 137-161.

Ledoux, L., Fourment, N., Maksud, F., Delluc, M., Costamagno, S., Goutas, N., Klaric, L., Laroulandie, V., Salomon, H., Jaubert, J., 2016. Traces of human and animal activity (TrAcs) in Cussac Cave (Le Buisson-de-Cadouin, Dordogne, France): Preliminary results and perspectives, Quaternary International.

Mallegni, F., Fabbri, P.F., 1995. The human skeletal remains from the upper palaeolithic burials found in Romito cave (Papasidero, Cosenza, Italy), Bulletins et Mémoires de la Société d'anthropologie de Paris 7, 99-137.

Maureille, B., Rougier, H., Houët, F., Vandermeersch, B., 2001. Les dents inférieures du néandertalien Regourdou 1 (site de Regourdou, commune de Montignac, Dordogne), Paléo $13,183-200$.

Mittnik, A., Wang, C.-C., Svoboda, J., Krause, J., 2016. A Molecular Approach to the Sexing of the Triple Burial at the Upper Paleolithic Site of Dolní Věstonice, PloS one 11, e0163019.

Murail, P., Brůžek, J., Houët, F., Cunha, E., 2005. DSP: a tool for probalistic sex diagnosis using worldwide variation in hip-bone measurements, Bulletins et Mémoires de la Société d'Anthropologie de Paris 17, 167-176.

Mussi, M., Bahn, P., Maggi, R., 2008. Parietal art discovered at Arene Candide Cave (Liguria, Italy), Antiquity 82, 265-270.

Paoli, G., Parenti, R., Sergi, S., 1980. Gli scheletri mesolitici della caverna delle Arene Candide (Liguria), Memorie dell'Istituto Italiano di Paleontologia Umana Roma, 33-154.

Pettitt, P., 2013. The Palaeolithic origins of human burial, Routledge.

R Core Team, 2016. R: A language and environment for statistical computing, R Foundation for Statistical Computing, Vienna, Austria. 
Riel-Salvatore, J., Gravel-Miguel, C., 2013. Upper Palaeolithic mortuary practices in Eurasia: a critical look at the burial record, in: Tarlow, S., Nilsson Stutz, L. (Eds.), The Oxford handbook of the archaeology of death and burial, Oxford University Press, Oxford, pp. 303346.

Samsel, M., Knüsel, C.J., Villotte, S., 2016. Reassessment of the sex and age-at-death of the Azilian skeleton from Le Peyrat 5, Saint-Rabier (Dordogne, France), BMSAP, 1-8.

Schmitt, A., 2005. Une nouvelle méthode pour estimer l'âge au décès des adultes à partir de la surface sacro-pelvienne iliaque, Bulletins et Mémoires de la Société d'Anthropologie de Paris $17,89-101$.

Sergi, S., Paoli, G., Parenti, R., 1974. Il giovane paleolitico della caverna delle Arene Candide.

Sládek, V., Trinkaus, E., Hillson, S.W., Holliday, T.W., 2000. The people of the Pavlovian Skeletal catalogue and osteometrics of the Gravettian fossil hominids from Dolní Věstonice and PAvlov, Academy of Sciences of the Czech Republic, Institute of Archaeology, Brno.

Sparacello, V.S., Rossi, S., Pettitt, P., Roberts, C.A., Riel-Salvatore, J., Formicola, V., n.d. New insights on Final Epigravettian funerary behaviour at Arene Candide Cave (Western Liguria, Italy) from osteological and spatial analysis of secondary bone deposits, J Anthropol Sci (in revision).

Tarsi, T., Noto, F., Martinez-Labarga, C., Giampaolo, R., Babalini, C., Scano, G., Contini, I., Lorente, J., Lorente, M., Pacciani, E., 2006. Ricostruzione della storia genetica per via materna delle comunità paleolitiche dei Balzi Rossi, delle Arene Candide e del Romito, e di quelle neolitiche ed eneolitiche di Samari e di Fontenoce di Recanati, La cultura del morire nelle società preistoriche e protostoriche italiane dal paleolitico all'età del rame, origines, progetti, III. Istituto Italiano di Preistoria e Prostoria, Firenze, 315-346.

Trinkaus, E., 2015. The appendicular skeletal remains of Oberkassel 1 and 2, in: Giemsch, L., Schmitz, R.W. (Eds.), The Late Glacial Burial from Oberkassel Revisited, Verlag Philipp von Zabern, DARMSTADT, pp. 75-132.

Trinkaus, E., Buzhilova, A.P., Mednikova, M.B., Dobrovolskaya, M.V., 2014. The People of Sunghir: Burials, Bodies and Behavior in the Earlier Upper Paleolithic, Oxford University Press, New York.

Trinkaus, E., Svoboda, J., 2006. Early modern human evolution in Central Europe - The people of Dolní Věstonice and Pavlov, Oxford University Press, Oxford.

Vallois, H.-V., Billy, G., 1965. Nouvelles recherches sur les hommes fossiles de l'abri de Cro-Magnon, L'Anthropologie (Paris) 69, 47-74.

Velemínská, J., Brůžek, J., 2008. Early modern humans from Předmostí, a new reading of old documentation, Academia, Praha.

Vercellotti, G., Alciati, G., Richards, M.P., Formicola, V., 2008. The Late Upper Paleolithic skeleton Villabruna 1 (Italy): a source of data on biology and behavior of a 14.000 year-old hunter, J Anthropol Sci 86, 143-163.

Villotte, S., 2009. Enthésopathies et activités des hommes préhistoriques - Recherche méthodologique et application aux fossiles européens du Paléolithique supérieur et du Mésolithique, Archeopress, Oxford. 
Villotte, S., Brůžek, J., Henry-Gambier, D., 2011. Révision de l'âge au décès et du sexe des sujets adultes gravettiens, in: Goutas, N., Klaric, L., Pesesse, D., Guillermin, P. (Eds.), À la recherche des identités gravettiennes : actualités, questionnements et perspectives, Société préhistorique française, pp. 209-216.

Villotte, S., Samsel, M., Sparacello, V., 2017. The paleobiology of two adults skeletons from Baousso da Torre (Bausu da Ture) (Liguria, Italy): Implications for Gravetiian lifestyle, Comptes Rendus Palevol http://dx.doi.org/10.1016/j.crpv.2016.09.004.

Villotte, S., Santos, F., Courtaud, P., 2015. In situ study of the Gravettian individual from Cussac cave, locus 2 (Dordogne, France), American Journal of Physical Anthropology 158, 759-768.

von Bonin, G., 1935. The Magdalenian skeleton from Cap-Blanc in the Field Museum of Natural History, University of Illinois, Urbana.

Weber, G.W., Bookstein, F.L., 2011. Virtual anthropology: a guide to a new interdisciplinary field, Springer.

Wu, X.-J., Xing, S., Trinkaus, E., 2013. An Enlarged Parietal Foramen in the Late Archaic Xujiayao 11 Neurocranium from Northern China, and Rare Anomalies among Pleistocene Homo, PLOS ONE 8, e59587. 